\title{
The Effect of Building Closures due to COVID 19 on the Perceptions and Practices of School Counselors
}

\author{
Louis S. Nadelson ${ }^{1}$, Valerie G. Couture ${ }^{1, *} \&$ Odunola Oyeniyi ${ }^{1}$ \\ ${ }^{1}$ Leadership Studies Department, College of Education, University of Central Arkansas, United States \\ *Correspondence: Leadership Studies Department, University of Central Arkansas, 201 Donaghey Avenue, \\ Mashburn Hall 220, Conway, AR 72035, United States. Tel: 1-501-450-5209. E-mail: vcouture@uca.edu. \\ https://orcid.org/0000-0002-4438-0194
}

Received: November 5, 2021

Accepted: November 27, $2021 \quad$ Online Published: December 6, 2021

doi:10.5430/wje.v11n6p1

URL: https://doi.org/10.5430/wje.v11n6p1

\begin{abstract}
With school buildings shuttering due to COVID-19, school counselors' work needed to shift to virtual environments. The shift in operations led us to wonder about school counselors' perceptions and practices in these new and unfamiliar conditions. In our mixed-methods cross-sectional study, we gathered quantitative and qualitative data from 89 school counselors. Our findings include evidence of the counselors feeling disconnected from their students, lack of technology and student access, privacy issues, limited preparation to counsel in virtual environments, and work and life balance. We follow our results with a discussion, related implications, and directions for future research.
\end{abstract}

Keywords: virtual counseling, building closures, working remotely, role shifts

\section{Introduction}

During the COVID-19 pandemic, K-12 school counselors worked virtually to minimize personal contact with students and colleagues to slow the coronavirus's spread. The action resulted in many school counselors providing counseling virtually using tools such as Skype, Zoom, phone calls, and Google Meet, irrespective of their previous experience working virtually (Békés \& Aafjes-van Doorn, 2020). School counselors are mentors and confidantes who can help students navigate feelings, dilemmas, and thoughts they may not understand. The COVID-19 pandemic highlighted the instability of relying on one counselor, or just a few, to guide hundreds of students through academic obstacles, prepare them for an unpredictable future, and triage their mental health crises (MacMullin et al., 2020). Even as the student-to-counselor ratio drops nationally, many states remain well above the 250-to-1 recommended by the American School Counselor Association (American School Counselor Association [ASCA], 2012).

In addition to being away from counselors, students were out of sight of teachers and peers, two groups that helped counselors recognize who might need their service. Nationally, school counselors struggled to find solutions to logistically and ethically approach their work virtually (Jobes et al., 2020). School counselors often focused on students' ecological systems, including their families, schools, neighborhoods, and religious groups, as well as the ways those systems contributed to children and adolescents' development (Rosen et al., 2020). When schools and other organizations temporarily close, many of these ecological systems were temporarily misplaced (Rosen et al., 2020). To gauge how students coped with the COVID-19 pandemic, school counselors attempted to connect with all students, not just those considered high-risk (Karaman et al., 2021). During the COVID-19 pandemic, students experienced increased psychological symptoms, such as anxiety, depression, and somatization (Karaman et al., 2021). The stressful situation increased the critical need for school counselors and educators to connect with their students even though they could not meet at a school (Karaman et al., 2021).

Since school counselors serve students from various backgrounds, including socioeconomic, it is essential to continue to empirically document school counselors' challenges in providing their services virtually. The reason to document the various challenges school counselors face when trying to serve students virtually is so the gaps in services can be addressed. This knowledge was needed by school administrators, school counselors, teachers, and those preparing school counselors to work in the field. Our literature search showed a gap in empirical studies documenting the 
outcome of temporary school building closures on school counselors' perceptions and practices. The lack of empirical research motivated us to empirically document school counselors' perceptions and practices working virtually due to temporary building closures because of COVID-19.

\section{Literature Review}

\subsection{Roles of School Counselors}

There are four themes incorporated into the ASCA National Model (ASCA, 2012) defining the role of a school counselor: leadership, collaboration, advocacy, and systemic change. Leadership is a responsibility the school counselors take to help students have access to life-changing opportunities. Collaborating with teachers and administrators is a way to effectively implement the change needed to benefit students, schools, districts, and the state. Moreover, collaborating also entails school counseling professionals working with all stakeholders towards common goals of equity, access, and academic accomplishment for all students. School counselors work to build successful working relationships among students, parents, and colleagues to advocate for all the parties involved. Working as a team helps school counselors to collect and analyze data to identify and make the changes needed to achieve the school goals. Advocacy is the third theme in which school counselors efficiently work with all students to encourage excellent school performance. Systemic change is an aspect of school counselors' work as they frequently hold critical data about students. When student data is compiled into school-wide data, school counselors, in collaboration with other school leaders, can use evidence-based decision-making to create positive systemic change that benefits all students (ASCA, 2005; Blake et al., 2014). We will now explore the specific contexts of school counselor roles that are most likely impacted when school continues with the school buildings closed.

\subsubsection{Student Support}

School counselors face many challenges like students dropping out, students with unstable social-emotional coping, and limited resources for student and family support. Effectively addressing these challenges requires professional school counselors to collaborate with teachers, administrators, and families to ensure efforts to achieve common goals (ASCA, 2005; Wagner, 1998). School counselors are an essential part of the educational leadership team. They provide valuable assistance to students at the elementary, middle, and high school levels (Tompsett \& Toro, 2010). According to Dunlop (2016), school counselors play an essential role in the lives of students. One of a school counselor's primary roles is supporting students with psychological or emotional issues. Many children and teenagers may find it difficult to discuss personal matters with their parents or peer groups. School counselors are trusted adults with whom students can confidentiality share personal issues (Dvorsky et al., 2014; Radford et al., 2016). Beyond social-emotional support for students, school counselors are frequently responsible for supporting individualized student planning, teaching the counseling core curriculum, and crisis response. A portion of school counselors' time is commonly dedicated to indirect services called system support (Wood et al., 2013). As students progress through their education, they begin to explore future career goals. School counselors offer guidance to students exploring their career options. School counselors provide students with career details and strategies to achieve their goals (Strawser et al., 2000; McMahon et al., 2014). Thus, career counseling is a critical role for many school counselors. Fulfilling their expectations is challenging under normal conditions; therefore, the shift to filling the expectations when school buildings close may make school counselors' challenges daunting.

\subsubsection{Social-Emotional Support}

A student's life commonly involves a mixture of complex interactions with friends, parents, and teachers. Sometimes these interactions can become contentious. When students' relationships become problematic, they may rely on school counselors for therapeutic advice or serve as mediators (Havlik \& Bryan, 2015). As a result, students will know that they have someone who can help them to resolve conflicts (Altena et al., 2010). School counselors strive to be approachable and available to students who have issues so they can rely on counselors when needed (ASCA, 2014). The close work between students in distress and school counselors is enabled by counselors being readily accessible in the school. The lack of proximity due to school closures may complicate or hinder school counselors' ability to support students experiencing stress.

\subsubsection{Special Education Support}

Students with special needs often require specific interventions and school counselors have a vital role in ensuring that the students receive the anticipated services (Havlik \& Bryan, 2015). School counselors also often take responsibility to ensure that programs for special needs students are implemented properly (Miller, 2011). When school buildings are closed, there is a greater demand placed on school counselors to monitor the expected supports for students with 
special needs. Further, school counselors may have to facilitate offering alternative services for students with special needs to fulfill the school's expectation for providing the required support.

\subsubsection{Leading School-Wide Initiatives}

School counselors are frequently the lead in efforts to create healthy and non-toxic school environments. As violence has become a common issue in schools, school counselors strive to detect and reduce potential catalysts, such as bullying (Woods, \& Domina, 2014). Teachers and school administrators face challenges in reducing the bullying rate due to their focus on other primary responsibilities. Thus, school counselors and other mental health professionals are primarily responsible for leading anti-bullying programs and services (Bachman et al., 2011). School counselors collaborate with administrators and teachers to create and implement policies to reduce bullying to the nearest minimum (ASCA, 2012). Being in the building with the students, administrators, and teachers allows school counselors to directly contact those who support and need anti-violence intervention. However, school-related bullying and violence may continue to occur when school buildings close, but it may occur distal to the counselors, limiting their ability to address the issue.

\subsubsection{Forming and Maintaining the School Community}

Counselors provide a sense of belongingness to the school community by developing inclusive, preventative, and developmental interventions. The school counselor and other faculty formulate successful strategies for youth success. For a school community to progress, the following eight core elements must be present: safety, shared ownership, consistency, fun, collaboration, connectedness, empowerment, and respect (Pyne, 2011). School counselors use a combination of the following tactics to achieve a positive school community: relationship building, recognition, visibility, developmental guidance, problem-solving, evaluation, needs assessment, and program or facility facilitation techniques (Erford, 2011). It takes the entire school staff for the eight-core elements to be achieved, with teachers, parents, counselors, and students collaborating to develop effective strategies to support student goal achievement (Dahir \& Stone, 2012; Freeman et al., 2015; Woods \& Domina, 2014; Zalaquett \& Chatters, 2012). In such endeavors, the school counselor's role is to encourage academic, career, personal or social development, facilitate learning opportunities, and help students develop the skills needed to succeed. School counselors' coordination of these efforts requires extensive communication, which is substantially more complicated or impossible when school buildings are closed.

\subsection{Use of Technology as a School Counselor}

As technology has evolved all professions, it has also influenced school counseling. Like other professionals, school counselors use email and social media for information delivery and communication with stakeholders (Steele et al., 2014). Another technology-related activity of school counselors is promoting and monitoring students' safe and responsible use of technology to support their academic, career, and personal/social achievement (ASCA, 2017). For example, the use of online resources, such as career assessments, college information, and occupation trends research, are used by school counselors to assist students in career decision-making (Steele et al., 2014). While contemporary school counselors know how to gather and apply online resources to help students with academic and career goals, the use of technology to deliver individual counseling has not been the norm as the students meet face-to-face in the school counselor's office.

The extent that school counselors use technology to deliver school counseling services has not been extensively researched (Steele et al., 2014). The limited research has shown that school counselors are more likely to use technology at work in the following activities: professional development, collaboration, consultation, and program management (Sears \& Granello, 2002; Wilczenski \& Coomey, 2006). Sabella and Halverson (2004) report that building a virtual community to better connect with students, parents, administrators, teachers, and other stakeholders, is one way to build collaborations that benefit students' academic, career, and personal/social development. Yet, school counselors have been found to lack comfort and skills when using technology (Glasheen et al., 2013; Van Horn \& Myrick, 2001). Professional counseling organizations emphasize that school counselors must maintain their professional ethics related to student confidentiality when using technology to communicate with students (ASCA, 2018; The National Board for Certified Counselors [NBCC], 2012). The potential use of technology for school counseling and the challenges school counselors may face in using technology may complicate their work when they are limited to use technology to do their work due to school building closures. Thus, there is a need for additional research to examine the school counselors' beliefs about their capability of using technology professionally and ethically to provide virtual counseling services to students.

The popularization of virtual K-12 schools has required some school counselors to work exclusively in virtual 
environments using technology. However, most school counseling has been done and continues to occur in brick-and-mortar schools (Osborn et al., 2015). School counselors who work full-time for virtual schools must provide programming to ensure students can reach their potential using the virtual school counseling platform (ASCA, 2017). The guidelines ASCA (2017) maintains virtual school counselors must adhere to include; (a) following the same ethical guidelines as a face-to-face school counselor, (b) recognizing the limitations of virtual school counseling, (c) implementing procedures for students to follow in emergencies when the school counselor is not available, (d) mitigating the limitations of confidentiality, (e) informing both the student and parent/guardian of the benefits and limitations of virtual school counseling, (f) educating students on how to participant in electronic school counseling, and $(\mathrm{g})$ incorporating lessons that align with the three school counseling domains; career, academic, and personal/social concerns. While these guidelines may be helpful, the relatively rare occurrence of fully online school counseling suggests many counselors have not been prepared to implements the ASCA guidelines. The potential lack of preparation justifies research on what school counselors perceive would benefit them in providing virtual counseling services.

\subsection{Rapid Change, Mental Distress, and Change in the Workplace due to COVID-19}

Few events in recent history have provided the opportunity to examine the impact of rapid change on work performance and engagement. However, the sudden change in the workplace due to COVID-19 resulted in abrupt changes to how schools (and other businesses) functioned. Unlike natural disasters, which are typically local or regional events, COVID -19 was a pandemic with a worldwide impact. Recognizing the potential for disruption by an event to the workplace, Schouten et al. (2004) argue organizations have a responsibility to plan for and support employees when disasters disrupt the workplace. We embrace this perspective and maintain that school leadership was responsible for supporting school counselors as schools shifted from in-person to virtual work as school buildings closed due to the pandemic. Thus, there was a warrant for examining school counselors' perceptions of their administrative leaders' support when the school buildings were closed.

Many people experience stress due to the trauma associated with workplace changes (van Heugten, 2012). The trauma may result from multiple factors. With COVID-19, the trauma of moving from in school to virtual learning and counseling led to stress due to lack of connectivity for online work and the challenges of working from home (e.g., lack of a quiet, confidential space), and isolation. Further adding to the stress were the challenges of maintaining counseling activities in a virtual environment that does not lend itself well to some counseling activities, particularly with children. Additional stress may have resulted from a lack of preparation for engaging in counseling in virtual environments. The emotional distress associated with the COVID-19 pandemic and response is likely to be shared by all (Pfefferbaum \& North, 2020; Twenge \& Joiner, 2020). The mental distress may have manifested in increased anxiety, substance abuse, or depression, further complicating the challenges associated with the need to rapidly shift the way work is done (Torales et al., 2020).

The stress of the shift from in-person to virtual work of school counselors may have been further exacerbated by a sense of responsibility to support at-risk students (Wong et al., 2020). The need to continue supporting students with mental health issues, societal challenges, and family problems in virtual environments may be particularly challenging, especially given the potential difficulties connecting online (Viner et al., 2020). Given the potential stress and challenges for school counselors to shift their work to entirely virtual, there is a justification for determining how the COVID-19 school building closures impacted their work.

\section{Method}

The researchers used both quantitative and qualitative research methods to collect data from school counselors. Our overarching research question was: How did school counselors respond to building closures due to COVID-19? To answer our research question, we developed this series of guiding research questions:

A. Were school counselors able to fulfill their role when their buildings closed?

B. How prepared were school counselors to continue to engage in their work during building closures?

C. How did building closures influence school counselors' perceptions of their role in the school?

D. What factors influenced the counselors' abilities to work in virtual environments?

E. How did school building closures impact school counselors' perceptions and practices vary with their personal and professional variables? 


\subsection{Participants}

We invited the 1091 school counselors listed on a publicly accessible mailing list to participate in our research project. We had 113 of those we invited to participate in our research click the survey link, which gave us a response rate of $8 \%$. Out of the 113 who began the survey, we had 89 participants complete at least $90 \%$ of the survey. On average, the participants were 46.81 years old $(S D=10.42)$ and worked as school counselors for an average of 11.10 years $(S D=$ 9.28). We had 86 participants identify as females, and four identify as males. The majority of the participants (86\%) identified themselves as White, $10 \%$ identified as Black, and $4 \%$ identified as "other." A small percentage (5\%) worked in schools with $0-25 \%$ students on free and reduced lunch, $17 \%$ in schools with $25-50 \%$ students on free and reduced lunch, $32 \%$ in schools with $50-75 \%$ students on free and reduced lunch, and $46 \%$ in schools with $75-100 \%$ students on free and reduced lunch. Almost two-thirds of the participants (61\%) lived in rural areas, $21 \%$ from suburban regions, and $18 \%$ in urban areas. About $40 \%$ worked in elementary level schools, $22 \%$ in middle schools, $26 \%$ in high schools, and $12 \%$ in other schools (e.g., K-12, 6-12, K-8). The majority of the participants (67\%) indicated that they had school responsibilities outside of counseling.

\subsection{Design}

We used a cross-sectional design using survey research to gather data from school counselors to determine what they were thinking and experiencing at a specific point in time (Setia, 2016). In our survey research, we used selected-response items to assess the prevalence of the phenomenon (Setia, 2016). We also used free-response items to gain a deeper understanding of the participants' lived experiences using a phenomenological approach (Creswell \& Creswell, 2017).

\subsection{Measure}

The novel situation of school counselors working from home or in schools without children in the building due to COVID-19 provided a warrant for us to create a new instrument for our research. Following the development of our guiding research questions, we independently generated multiple selected and free-response items aligned with each of the questions' focus. Collectively we reviewed the items we developed for alignment to the guiding research questions and redundancy. Our goal was to generate 20-25 items that were distributed evenly among the four guiding research questions.

Our final survey contained 24 items, with 20 selected-response items and four free-response items. The selected-response items were a mixture of positive and negative statements that the participants responded to using a five-point Likert scale ranging from "strongly disagree" (coded as 1) to "strongly agree" (coded as 5). The selected-response items included prompts such as, "I have had to change how I advise students planning for their next year" and "I put forth additional effort to stay connected with the teachers in my school" and "I have done remote counseling using technology prior to my school closing." The free-response items included prompts such as, "What limits your ability to engage in counseling activities due to school closure?" and "What are the particular challenges you have faced working from home?" We also included multiple demographic items such as age, school location, years of experience, and gender. Our instrument's internal consistency test revealed a Cronbach alpha of .78, indicating an acceptable reliability level.

\subsection{Data Collection}

Our data collection took place in the south-central region of the United States. We obtained 1162 school counselors' emails from a publicly accessible website; however, some counselors were listed more than once. After removing the duplicates, we reduced our email list to 1091 counselors. We emailed the counselors an invitation to participate in our research, which included a Qualtrics survey link. Our survey's first page included an IRB-approved letter of information and an item asking the counselors if they agreed to participate in the research. We collected data for two weeks, at which time we had not had a survey completed for three days. We had 89 of the invited counselors complete at least $90 \%$ of the selected response items, which provided us with an $8 \%$ response rate.

\subsection{Analysis}

\subsubsection{Quantitative Data}

We began our analysis by conditioning our dataset by removing the responses with less than $90 \%$ of the survey items completed. We then used the replace missing values with the series median using the SPSS function to generate responses for the remaining randomly distributed missing data points. We also reverse coded the responses to our negatively stated items. Once we completed the date conditioning, we calculated the means, standard deviations, and medians for analysis. We also coded the categorical data for use as factors in t-tests and ANOVA calculations as 
reported in our results.

\subsubsection{Qualitative Data}

We analyzed our data using inductive and deductive coding and thematic or content analysis (Creswell \& Creswell, 2017; Miles et al., 2014). The primary steps we used in coding our qualitative data included: (a) reducing the data to segments and giving the segments names, (b) combining the codes into broader themes, and (c) comparing the data in graphs, tables, and charts (Creswell, 2013).

We began our qualitative data analysis process by developing a set of codes aligned with our research questions and study constructs. Two out of the three researchers have backgrounds in school counseling and teach in a graduate school counseling program and used their expertise to guide the development of the a priori themes and codes (see Table 1 for a representative subset). We also remained open to emergent codes for responses we did not anticipate.

Table 1. A Representative Subset of Themes and A-Priori Codes Generated for Analysis

\begin{tabular}{|c|c|}
\hline Theme & Codes \\
\hline Technology/ Connectivity & Access to the internet, computer access, technical support \\
\hline Student Response & $\begin{array}{l}\text { Engaged students, lack of connecting with students, distracted by stimuli in } \\
\text { the home when on zoom. }\end{array}$ \\
\hline Confidentiality & $\begin{array}{l}\text { Students are reluctant to share over the phone, they have parents or siblings at } \\
\text { home that could overhear, parents are reluctant to allow private conversations. }\end{array}$ \\
\hline Personal Contact, Trust, Rapport & Impossible to hug or hold a hand or reach out and touch for comfort. \\
\hline $\begin{array}{l}\text { Lack of parental support } \\
\text { (Emergent code) }\end{array}$ & Parents not signing students up for virtual options. \\
\hline Working at home & $\begin{array}{l}\text { Multiple interruptions from family, establishing a consistent daily routine, } \\
\text { constraints of participating and feeling connected in ZOOM meetings, } \\
\text { completing paperwork, and keeping records. }\end{array}$ \\
\hline $\begin{array}{l}\text { Unable to connect with students } \\
\text { (lack of contact information) }\end{array}$ & $\begin{array}{l}\text { Changed phone numbers or disconnected phone services, accessing the office } \\
\text { to get materials needed. }\end{array}$ \\
\hline $\begin{array}{l}\text { Lack of experience working } \\
\text { online }\end{array}$ & $\begin{array}{l}\text { Body language issue, learning to handle interruptions, connecting with others } \\
\text { through video conferencing }\end{array}$ \\
\hline How to connect with students. & $\begin{array}{l}\text { Lack of resources among each household when using technology, student } \\
\text { access to technology and internet, locating students during pandemic, limited } \\
\text { communication with teachers/ administration. }\end{array}$ \\
\hline
\end{tabular}

To establish the trustworthiness of our research, we collectively coded several responses and discussed our interpretations and perceived alignments with our themes and codes. We then separately coded a subset of responses, compared our results, and discussed and resolved any variations in the coding. We continued this process until we achieved an intercoder consistency Cohen kappa greater than .80, indicating an acceptable coding consistency level (McHugh, 2012).

\section{Results}

\subsection{Ability to Fulfill Role as School Counselor}

Our first guiding research question asked, "Were school counselors able to fulfill their role when their buildings closed?" To answer this question, we calculated the descriptive statistics for the related selected-response items (see Table 2). We found the participants disagreed with changing how they were advising students for the next academic year $(M=2.02, S D=.83, \mathrm{Med}=2)$. The counselors were neutral with respect to being able to continue to provide 1-to-1 counseling services to at-risk students $(M=2.74, S D=1.05, \mathrm{Med}=3)$. The participants tended to agree that they could hold confidential meetings from home $(M=3.38, S D=1.23, \mathrm{Med}=4)$, they had to put forth additional effort to stay connected with the teachers they work with $(M=3.88, S D=.85, \mathrm{Med}=4)$, and receiving support from their principal during closure $(M=4.26, S D=.92, \mathrm{Med}=4)$. Overall, we found that the school counselors agreed that they 
could fulfill their role during school building closure with some additional effort.

Table 2. Means, Standard Deviations, and Medians for Items Aligned with Fulfilling School Role

\begin{tabular}{lcc}
\hline ITEM & M (SD) & Med \\
\hline I have had to change how I advise students planning for their next year. & $2.02(.83)$ & 2 \\
I have been able to continue to provide 1-1 counseling services to students at-risk. & $2.74(1.05)$ & 3 \\
I can hold confidential meetings from my home. & $3.83(1.23)$ & 4 \\
I put forth additional effort to stay connected with the teachers in my school. & $3.88(.85)$ & 4 \\
My principal has been very supportive of my work during the closure. & $4.26(.92)$ & 4 \\
\hline
\end{tabular}

We continued our analysis by examining the coded responses to our item asking the participants: "What limits your ability to engage in counseling activities due to school closure?" The coded responses illuminated multiple conditions that limited the school counselors' ability to fulfill their roles. In Table 3, we present the coded themes, the frequency of the codes, and representative responses aligned with the codes. Many of the participants shared that technology was an issue, particularly students having adequate access. Similarly, the participants shared that many students did not actively engage with technology for learning or counseling and indicated that confidentiality issues made counseling virtually difficult. Similarly, problems connecting with students led some counselors to feel out of touch with their students. Overall, the counselors shared multiple issues that limited their ability to provide support and services to students when their school building closed.

Table 3. Coded Theme, Frequencies, and Representative Responses aligned with Limits on Ability to Counsel Virtually

\begin{tabular}{|c|c|c|}
\hline Coded Theme & $\mathrm{N}$ & Representative Response \\
\hline Technology/ Connectivity & 33 & $\begin{array}{l}\text { The students for the most part do not have internet, or wi-fi access. Our school set } \\
\text { up wi-fi hotspots in areas for families to access but it was not really successful }\end{array}$ \\
\hline Student response & 22 & $\begin{array}{l}\text { Many of my most at-risk students are not actively engaging in our digital learning. It } \\
\text { has been very hard to reach these students and set up sessions. }\end{array}$ \\
\hline Confidentiality & 11 & ... they feel that they are not in a space that they can talk to me comfortably. \\
\hline Personal Contact, Trust, Rapport & 10 & $\begin{array}{l}\text { Students are reluctant to share over the phone. They might have parents or siblings } \\
\text { at home that could overhear. Parents are reluctant to allow private conversations. } \\
\text { I'm not sure that students perceive that someone on the phone can help them. }\end{array}$ \\
\hline $\begin{array}{l}\text { Lack of parental support } \\
\text { (Emergent code) }\end{array}$ & 10 & $\begin{array}{l}\text { Most of the student's parents do not answer the phone, either because of choice or } \\
\text { lack of minutes. They respond more often to text messages but with very short } \\
\text { responses. }\end{array}$ \\
\hline Working at home & 9 & $\begin{array}{l}\text { Mom of } 2 \text { ages } 5 \text { and } 7 \text { who need supervision, help with AMI and projects to keep } \\
\text { them busy and not on technology. }\end{array}$ \\
\hline $\begin{array}{l}\text { Unable to connect with students } \\
\text { (lack of contact information) }\end{array}$ & 8 & $\begin{array}{l}\text { Being able to reach the students that I need to counsel because of changed phone } \\
\text { numbers or disconnected phone services. }\end{array}$ \\
\hline Lack of experience working online & 4 & Getting students to zoom with me or watch recorded lessons \\
\hline
\end{tabular}

\subsection{Prepared to Engage}

Our second guiding research question asked, "How prepared were school counselors to continue to engage in their work during building closures?" To answer this question, we calculated the descriptive statistics for the related selected-response items (see Table 4). We found the counselors disagreed with having done remote counseling before the building closure $(M=2.15, S D=1.19, M e d=2)$ and to being prepared for the school closure $(M=2.31, S D=.98$, $M e d=2)$. The participants agreed they had to purchase technology for working at home $(M=3.88, S D=1.20, \operatorname{Med}=$ 
$4)$, but had a dedicated workspace $(M=3.89, S D=1.09$, Med $=4)$. The participants strongly agreed that they had adequate internet connections at home to work online $(M=4.26, S D=1.10, \mathrm{Med}=5)$. Overall, the participants seemed to have internet access and the space needed to conduct their work online but seemed to lack experience with the process and needed additional technology to work at home.

Table 4. Means, Standard Deviations, and Medians for Items Aligned with Prepared for Building Closure

\begin{tabular}{lcc}
\hline ITEM & M (SD) & Med \\
\hline I have done remote counseling using technology prior to my school closing. & $2.15(1.19)$ & 2 \\
I was prepared for the school closure. & $2.31(.98)$ & 2 \\
I had to purchase additional technology to work from home. & $3.88(1.20)$ & 4 \\
I have a dedicated workspace at home. & $3.89(1.09)$ & 4 \\
I have adequate internet access to do my work from home. & $4.26(1.10)$ & 5 \\
\hline
\end{tabular}

We continued our analysis by looking at the responses to our qualitative prompt, which asked: "How can school counselor preparation programs better equip future school counselors to provide virtual school counseling services?" Our expectation was for the answers to illuminate both suggestions for counselor preparation programs and indications of preparedness to counsel virtually. We found the counselors perceived a need to find creative ways to connect with the students and similarly communicated a need to gain a deeper understanding of how to communicate with students in virtual environments (see Table 5). Several participants included a need to learn more about using specific tools such as learning management systems. We found many counselors perceived a need to inform teachers what they were doing virtually. The perceived need suggested the counselors felt a need to publicize their professional engagement and the importance of their work. The participants indicated a benefit to learning about using technology tools and engaging in counseling in virtual environments while also indicating a lack of preparation for pivoting to counseling online due to building closures.

Table 5. Coded Construct, Frequencies, and Representative Responses aligned with Support from Preparation Programs

\begin{tabular}{lcl}
\hline \multicolumn{1}{c}{ Coded Construct } & Frequency & \multicolumn{1}{c}{ Representative Response } \\
\hline $\begin{array}{l}\text { How to connect with students. } \\
\text { Practicing online counseling session }\end{array}$ & 24 & $\begin{array}{l}\text { I learned to video myself, giving talks about caring, feelings, etc. } \\
\text { By offering virtual counseling courses and teaching us how to } \\
\text { utilize technology to enhance our counseling programs. }\end{array}$ \\
$\begin{array}{l}\text { Learning about useful technology tools } \\
\begin{array}{l}\text { Potential variations in responsibility } \\
\text { Learning Google classroom. }\end{array}\end{array}$ & 16 & $\begin{array}{l}\text { I've heard multiple educators voice questions about what } \\
\text { counselors are doing during this time. }\end{array}$ \\
$\begin{array}{l}\text { Advocacy for the importance of } \\
\text { counseling. }\end{array}$ & 10 & $\begin{array}{l}\text { We have to find a way to show that we are necessary and vital } \\
\text { and can continue to work. }\end{array}$ \\
$\begin{array}{l}\text { Lack of experience with online } \\
\text { counseling }\end{array}$ & 8 & $\begin{array}{l}\text { Future counselors need experience with virtual counseling } \\
\text { services, so they are prepared. }\end{array}$ \\
\hline
\end{tabular}

\subsection{Shifts in Perceptions of the Role of a School Counselor}

Our third guiding research question asked, "How did building closures influence school counselors' perceptions of their role in the school?" To answer this question, we calculated the descriptive statistics for the related selected-response items (see Table 6). We found the participants tended to disagree with school closures limiting the ability to care for students $(M=2.27, S D=1.06, \mathrm{Med}=2)$. The participants were neutral toward changes in principal's valuing their work $(M=3.04, S D=.93, M e d=3)$ and changes in the confidence in their ability to do their work $(M=$ $3.28, S D=1.14, M e d=3)$. The participants tended to agree that they felt out of touch with their schools $(M=3.65, S D$ $=1.05, \mathrm{Med}=4)$ yet continued to collaborate with other professionals during the building closures $(M=3.28, S D=$ 1.14$, Med $=4)$. 
Table 6. Means, Standard Deviations, and Medians for Items Aligned with Perceptions of Role Due to Shifts in Practice because of COVID-19

\begin{tabular}{lcc}
\hline \multicolumn{1}{c}{ Item } & M*(SD) & Med \\
\hline The school building closure has limited my ability to care for my students. & $2.27(1.06)$ & 2 \\
My role in the school has been more valued by school administration due to the pandemic. & $3.04(.93)$ & 3 \\
The school closure has affected my confidence in my ability to be a professional school counselor. & $3.28(1.14)$ & 3 \\
I feel out of touch with my school. & $3.65(1.05)$ & 4 \\
I continue to collaborate with teachers, principals, and staff during the school closure. & $4.03(.85)$ & 4 \\
\hline
\end{tabular}

* Scale from 1 "Strongly Disagree" to 5 "Strongly Agree"

We continued answering our guiding research question by exploring the responses to our prompt, stating, "Please share the additional roles are you now fulfilling in your school." We found multiple participants sharing they were involved in providing essential supplies (e.g., food, hygiene, and school supplies) to students and their families (see Table 7). The counselors indicated they became involved in facilitating teacher-student interactions and monitoring student learning, engagement, and progress. A small number of participants shared they experienced no change in their duties and engaged in activities that were within the realm of expectations for school counselors. However, some participants shared the timing of the activities or who they were working with had shifted.

Table 7. Coded Construct, Frequencies, and Representative Responses Aligned with Additional Roles

\begin{tabular}{|c|c|c|}
\hline Construct & Frequency & Representative Response \\
\hline $\begin{array}{l}\text { Food and hygiene and school } \\
\text { supplies and housing (resources) to } \\
\text { families }\end{array}$ & 11 & $\begin{array}{l}\text { Delivery of food. This allows me to make face-to-face contact with } \\
\text { students and families. }\end{array}$ \\
\hline $\begin{array}{l}\text { Coordinating student-teacher } \\
\text { contact }\end{array}$ & 6 & $\begin{array}{l}\text { I am reaching out to family's teachers have not been able to make } \\
\text { contact with. }\end{array}$ \\
\hline Monitoring Student Learning & 5 & $\begin{array}{l}\text { I am responsible for nine students in which I make sure that they are } \\
\text { completing their AMI work, and I meet with them twice a week } \\
\text { through zoom. }\end{array}$ \\
\hline Planning for re-entry & 5 & $\begin{array}{l}\text { This is the time when I am usually working on perfecting the master } \\
\text { schedule and creating rosters for next year, so I am doing this. }\end{array}$ \\
\hline No Additional Roles & 3 & There were no additional roles given to me. \\
\hline Coordinating social media & 3 & $\begin{array}{l}\text { I am the parental involvement coordinator and manage our school's } \\
\text { social media accounts. They have become a lifeline to communication } \\
\text { for many parents and students during this time. }\end{array}$ \\
\hline Online counseling & 2 & $\begin{array}{l}\text {...offered services by Zoom to parents if a student needs counseling. I } \\
\text { have not had parents request services by virtual options. }\end{array}$ \\
\hline $\begin{array}{l}\text { Social-Emotional Learning } \\
\text { Resources }\end{array}$ & 2 & $\begin{array}{l}\text { I mailed out support information to the students I saw } 1-1 \text { before the } \\
\text { pandemic. I was able to post information on how to talk with your child } \\
\text { about COVID-19 and explain to them what is going on. }\end{array}$ \\
\hline $\begin{array}{l}\text { Coordinating LMS and student } \\
\text { assignments }\end{array}$ & 1 & $\begin{array}{l}\text { I am responsible for nine students in which I make sure that they are } \\
\text { completing their AMI work, and I meet with them twice a week } \\
\text { through zoom. I also oversee the AMI platform along with my } \\
\text { principal. }\end{array}$ \\
\hline $\begin{array}{l}\text { Working more directly with the } \\
\text { social worker }\end{array}$ & 1 & Working more directly with the social worker, training new counselor \\
\hline
\end{tabular}




\subsection{Virtual Work Environment}

Our fourth guiding research question asked: "What factors influenced the counselors' abilities to work in virtual environments?" We began answering this item by calculating the means, standard deviations and medians for the related selected-response items (see Table 8). We found the participants tended to disagree that their students have adequate internet services at home $(M=2.57, S D=1.13, \mathrm{Med}=2)$, their students having adequate access to technology at home $(M=2.61, S D=1.15, \mathrm{Med}=2)$, and their students being provided free internet access $(M=2.64, S D=1.28$, Med =2). The participants were neutral toward school closures affecting their mental health $(M=3.08, S D=1.17, M e d$ =3). The participants agreed that they were able to quickly adapt to their school building closure $(\mathrm{M}=3.61, \mathrm{SD}=.95$, $\mathrm{Med}=4)$ and were supported by their administration to work virtually $(M=4.03, S D=.85, \mathrm{Med}=4)$. Thus, the participants recognized their students' limitations to connect with them, while for the most part, the counselors were positioned to work virtually.

Table 8. Means, Standard Deviations and Medians for Items Aligned with Working in Virtual Environments

\begin{tabular}{lcc}
\hline \multicolumn{1}{c}{ Item } & M (SD) & Med \\
\hline My students have adequate internet service at home. & $2.57(1.13)$ & 2 \\
My students have adequate access to technology at home. & $2.61(1.15)$ & 2 \\
An internet provider in my area provides free internet access to students. & $2.64(1.28)$ & 2 \\
The school building closure has had an effect on my mental health and wellbeing. & $3.08(1.17)$ & 3 \\
I adapted quickly to my school building closing. & $3.61(.95)$ & 4 \\
I have the support from the administration I need to be effective remotely. & $4.03(.85)$ & 4
\end{tabular}

We continued our analysis by examining the participants' responses to our free response prompt, "What are the particular challenges you have faced working from home?" Our analysis revealed that many counselors were concerned with technical issues and counseling online (see Table 9). Several participants shared issues of balancing family and work, including time management and an appropriate space to work at home. Multiple participants mentioned communication issues and challenges connecting with students and other professionals who worked in their schools (e.g., teachers, administrators). Thus, the school counselors focused on the challenges and issues of working at home, technology, and getting and staying connected with others.

Table 9. Coded Construct, Frequencies, and Representative Responses Aligned with Challenges

\begin{tabular}{|c|c|c|}
\hline Coded Construct & Frequency & Representative Response \\
\hline Technology/ Connectivity & 21 & $\begin{array}{l}\text { Intermittent internet access when I am providing counseling or meeting } \\
\text { with students. Students were unable to participate. }\end{array}$ \\
\hline Balancing family and work & 13 & $\begin{array}{l}\text { I have small children that I have to help with AMI work, and they also meet } \\
\text { twice a week on zoom for instruction, and we share devices. So, I have to } \\
\text { work around their scheduled Zoom meeting to complete my work. }\end{array}$ \\
\hline $\begin{array}{l}\text { Lack of experience counseling } \\
\text { online }\end{array}$ & 12 & $\begin{array}{l}\text { Learning how to integrate additional technology to deliver effective lessons } \\
\text { and group meets. Still learning and compiling lessons. }\end{array}$ \\
\hline $\begin{array}{l}\text { Communication challenges } \\
\text { with students and parents } \\
\text { (Emerging) }\end{array}$ & 10 & $\begin{array}{l}\text { Not being able to have access to all students and parents has been a } \\
\text { struggle. }\end{array}$ \\
\hline $\begin{array}{l}\text { Communication with } \\
\text { co-workers }\end{array}$ & 9 & $\begin{array}{l}\text { Some teachers are more willing than others to reach out and let me know } \\
\text { when a child needs help. }\end{array}$ \\
\hline Time Management & 8 & $\begin{array}{l}\text { The ability to be a mother to my children and help them navigate through } \\
\text { their work, process their feelings and emotions and continue to work and } \\
\text { attend all of the required Zoom meetings. }\end{array}$ \\
\hline A shift in role responsibilities & 6 & Delivering food to homes daily. \\
\hline Appropriate workspace & 5 & Separating work from home has been hard without an office. \\
\hline
\end{tabular}




\subsection{Influence of Personal and Professional Variables}

Our fifth guiding research question asked, "How did school building closures impact on school counselors' perceptions and practices vary with their personal and professional variables?" To answer this question, we calculated the composite variables for our four research domains - change in role, school preparation to shift to virtual counseling, perceptions of their role as counselor, and working in virtual environments. We then calculated the correlations between the variables (see Table 10) and found all variables significantly correlated. The results indicate that shifts in roles, preparation to work in virtual environments, counseling role perceptions, and working in virtual environments are positively related, such that higher scores in one area is likely to indicate higher scores in the other areas.

Table 10. Correlations between Composite Variables

\begin{tabular}{llcccc}
\hline & M (SD) & Shift in Role & $\begin{array}{c}\text { Prepared to Work } \\
\text { Virtually }\end{array}$ & $\begin{array}{c}\text { Perceptions of } \\
\text { Role }\end{array}$ & $\begin{array}{c}\text { Virtual Work } \\
\text { Environment }\end{array}$ \\
\hline Shift in Role & $3.35(.51)$ & - & $.409^{* *}$ & $.472^{* *}$ & $.460^{* *}$ \\
Prepared to Work Virtually & $3.30(.64)$ & - & $.506^{* *}$ & $.352^{* *}$ \\
Perception of Role & $3.33(.60)$ & & - & $.429^{* *}$ \\
Virtual Work Environment & $3.09(.65)$ & & - \\
\hline
\end{tabular}

** Correlation is significant at the 0.01 level (2-tailed).

We continued our analysis using the personal and professional variables as factors or independent variables to determine the relationship with the composite variables. We found a significant difference $(t(43)=2.40, p=.02)$ for working in virtual environments between counselors working at schools with $0-25 \%$ free and reduced lunch $(M=3.73$, $S D=.68, N=5)$ and those working at schools with $75-100 \%$ free and reduced lunch $(M=2.94, S D=.70, N=40)$. Our findings indicate that those working in schools with higher socioeconomic status tended to have higher levels of resources and infrastructure for virtual counseling than counselors working in low socioeconomic schools.

We also found a difference in level of preparedness $(t(26)=2.98, p<.01)$ between counselors working in high schools $(M=3.63, S D=.63, N=23)$ compared to counselors working in $\mathrm{K}-12$ schools $(M=2.68, S D=.73, N=5)$. Our results suggest that high school counselors are more likely to have higher levels of preparation to fulfill their roles in virtual environments than counselors working in K-12 schools.

Our analysis revealed multiple differences between counselors who had no additional responsibilities and those with additional responsibilities (see Table 11). Our results indicate those counselors who did not have additional role responsibilities scored higher in being prepared to work virtually, experiencing shifts in their role, and being in positive virtual work environments than counselors who had extra responsibilities. Thus, our analysis suggests counselors with no other roles were more likely to assume additional roles due to building closures but were better prepared and more likely to be in environments that support virtual counseling.

Table 11. Differences in Composite Variables by Engagement in Additional Roles

\begin{tabular}{lllc}
\hline \multicolumn{1}{c}{ Composite Variable } & \multicolumn{1}{c}{ Group (N) } & M (SD) & t-statistic (sig) \\
\hline Prepared to Work Virtually & No Additional Role (29) & $3.52(.57)$ & $2.50(.014)$ \\
& Additional Roles (58) & $3.17(.64)$ & \\
\multirow{2}{*}{ Shift in Role } & No Additional Role (29) & $3.52(.45)$ & $2.36(.020)$ \\
& Additional Roles (58) & $3.25(.51)$ & $2.23(.029)$ \\
Virtual Work Environment & No Additional Role (29) & $3.28(.67)$ & \\
& Additional Roles (58) & $2.97(.60)$ & \\
\hline
\end{tabular}

We found no relationship or differences for age, caseload, years of counseling experience, gender, school community setting, and the number of students enrolled in the school. We could not test for ethnicity because we lacked adequate representation from multiple ethnic groups needed to provide the statistical power required for comparison. 


\section{Discussion and Implications}

The goal of our research was to determine how building closures due to COVID-19 influenced the perceptions and practices of K-12 school counselors. We recognize that the sudden disruption in the workplace and institutional organization due to the building closures was likely to significantly impact school counselors' roles, responsibilities, work activities, and effectiveness. We consider the school disruption due to COVID 19 mitigation efforts to be similar to events that impact school closures at the local level, such as hurricanes, flooding, fires, earthquakes, and other natural disasters. Therefore, by researching the impact of COVID 19 on the work of school counselors, we can predict the potential issues school counselors are likely to encounter in commonly occurring local events such as inclement weather. There are multiple lines of discussion and implications for our findings.

\subsection{Ability to Fulfill Role as a School Counselor}

Our finding that the school counselors were, for the most part, able to fulfill their roles with some additional effort suggests that the counselors were able to adapt to the new situation and apply new approaches to achieve expectations. However, some of our participants indicated that fulfilling their role was hindered by technology barriers and connecting with people suggesting that some students and faculty members may have received more support than others. We speculate that the increased reliance on technology in schools (e.g., the pervasive use of learning management systems, accessibility through cell phones) and the need to connect with families living in a range of conditions catalyzed the development of skills that the counselors were able to transfer to working remotely. However, the need for additional effort to stay connected with faculty members and students also reflected the challenges of fulfilling their roles during building closures (Hani, 2000). The implications for our findings are potential for students to need additional services during times of distress may be more challenging to attend to without extra effort, which may lead to burnout and additional stress experienced by school counselors (Wilder, 2018).

\subsection{Prepared to Engage}

Our finding that the participants, for the most part, had the necessary technology to work virtually but lacked the experience or knowledge of the process of virtual counseling may be a critical area that needs to be addressed in counselor professional preparation and development. Having access is undoubtedly essential for working virtually; however, the lack of knowledge or experience with virtual counseling is likely an even more significant barrier (Cronin et al., 2018). We speculate that the lack of a need or demand on school counselors to work virtually has been associated with a lack of consideration of the potential conditions needed to assure preparedness to engage in virtual counseling. We posit that the need to change approaches to their counseling practices due to building closures resulted in counselors experiencing a paradigm shift in considering alternative formats of engaging with students, parents, and teachers. We also speculate the consideration of alternative formats for communication had not been widely considered or required before the large-scale building closures. The need for preparation and experience with virtual counseling suggests that school counselor preparation programs should include content and practice for candidates to learn through experiences to use technology for virtual counseling (Olasile \& Emrah, 2020).

\subsection{Shifts in Perceptions of the Role of a School Counselor}

From our quantitative data, we found that the counselors struggled with keeping connected with their students but continued to work effectively with the faculty, staff, and administrators in their schools. We speculate that the stability in keeping connected to those working in their schools explains why the counselors retained relatively stable perceptions of their roles. However, from our qualitative data, we found that the counselors engaged in many activities that were not traditionally part of their role, such as distributing food and hygiene supplies to students' houses for their families. The implications of the expansion of responsibilities and the challenges of connecting with students are the increased potential for school counselors to experience increased stress, fatigue, and despair (Holman et al., 2018). Additionally, the expansion of their responsibilities may have required them to engage in activities that they were not prepared for, leaving them feeling incompetent or ineffective (Chandler et al., 2018). Thus, a well-connected network of peers who are also school counselors and experiencing similar conditions may be critical for mental health and professional support.

\subsection{Working in Virtual Environments}

We found the counselors tended to be in positions to work virtually and had the needed support, but also found the students tended to lack the resources to connect virtually with their counselors. Our finding reflects the ongoing digital divide, with some having resources and some not having the resources to connect virtually. A critical implication of our finding is counselors may be unable to connect with their students who are at risk and have high needs due to the students lacking the necessary resources. Other implications for our findings include issues of privacy and 
confidentiality issues for both the counselors and the students which may severely limited the open communication vital in situations of distress due to the potential lack of privacy when meeting virtual (Springer et al., 2020; Talmus, 2019). Our results certainly provide additional support for efforts to resolve the digital divide. Still, research is needed to explore how to effectively maintain confidential communication in virtual environments (Springer et al., 2020). The research may be especially critical when working with children who may not be open and honest if they think others may be able to hear them sharing their thoughts, feelings, or experiences.

\subsection{Personal and Professional Variables}

Our findings of differences in our composite measures based on social-economic status indicators and school type reflect the potential for the disparity in access to resources between communities. Further, the need to assume different roles due to building closures also seemed to negatively impact the levels of positive engagement in school counseling activities which aligns with the findings of Olasile and Emrah (2020). The implications for our results are similar to the conditions we discussed concerning working in virtual environments. The conditions of a digital divide in which those in some communities have readily accessible resources to work in virtual environments while those in different communities may have to put forth greater efforts to access the necessary resources. The lack of access or additional effort may hinder the ability of school counselors to work effectively virtually. Regardless of the ongoing challenges and barriers to solving the digital divide, school counselors' lack of access to connectivity and current technology is another challenge negatively influencing providing the support students need in some communities (Yablon, 2019). The lack of access to school counselors' support may result in some students experiencing ongoing social and emotional struggles that interfere with learning, further hindering their academic achievement (Holman et al., 2018).

\section{Limitations}

The first limitation of our study was the nature of our data collection, which involved using a survey. While we were able to gather a combination of both quantitative and qualitative data, we could not follow up with questions for clarification or explanation of responses. We did collect a range of responses that reflects a diversity of perspectives and trends in conditions. Yet, follow-up questions could have allowed for a greater in-depth understanding of the situation. Those seeking to build on our research may want to consider a combination of synchronous and asynchronous data collection that includes interviews and surveys for data collection.

The related limitation of our research is the potential for social-desirability bias of the participants, which may have motivated them to respond in socially acceptable ways but may not reflect the actual conditions. A similar potential solution to resolve this limitation is interviews and observations to triangulate the survey responses.

A third limitation of our research is the nature of our sampling. While we invited over $1000 \mathrm{~K}-12$ school counselors to participate in our study, they were all from the same region in the United States. It is possible that school counselors working in other locations may hold different perspectives and have different experiences. Replicating our study in other areas or regions would be an excellent direction for future research.

\section{Final Comments}

While the COVID 19 pandemic is a very unique situation, the shuttering of buildings is more common due to other conditions (e.g., natural disasters). Thus, the consideration of school counselors having to work remotely is not necessarily uncommon. Our research provides insight into the challenges and achievements that school counselors might encounter when there is an expectation to continue school when buildings are closed. We hope our research will benefit those who prepare school counselors and are considering options for developing a curriculum to meet the need to prepare candidates to engage in online counseling activities.

\section{Acknowledgements}

The authors appreciate all study participants.

\section{Conflicts of Interest}

We have no conflicts of interest to report. 


\section{References}

Altena, A., Brilleslijper-Kater, S., \& Wolf, J. (2010). Effective interventions for homeless youth a systematic review. American Journal of Preventive Medicine, 38(6), 637-645.

American School Counselor Association. (2005). The ASCA national model: A framework for school counseling programs (2nd ed.).

American School Counselor Association. (2012). The ASCA national model: A framework for school counseling programs (3rd ed.).

American School Counselor Association. (2014). ASCA mindsets \& behaviors for student success: K-12 college and career-readiness standards for every student.

American School Counselor Association. (2017). ASCA position statements: The school counselor and student safety and the use of technology. Retrieved from https://www.schoolcounselor.org/asca/media/asca/PositionStatements/PS_Technology.pdf

American School Counselor Association. (2017). ASCA position statements: The school counselor and virtual school counseling. Retrieved from https://www.schoolcounselor.org/asca/media/asca/PositionStatements/PS_Virtual.pdf

American School Counselor Association. (2018). ASCA position statements: The school counselor and confidentiality. Retrieved from https://www.schoolcounselor.org/asca/media/asca/PositionStatements/PS_Confidentiality.pdf

Bachman, R., Gunter, W. D., \& Bakken, N. W. (2011). Predicting feelings of school safety for lower, middle, and upper school students: A gender specific analysis. Applied Psychology in Criminal Justice, 7, 59-76.

Bauman, S. (2008). The role of elementary school counselors in reducing school bullying. The Elementary School Journal, 108(5), 362-375. https://doi.org/10.1086/589467

Békés, V., \& Aafjes-van Doorn, K. (2020). Psychotherapists' attitudes toward online therapy during the COVID-19 pandemic. Journal of Psychotherapy Integration, 30(2), 238-247. https://doi.org/10.1037/int0000214

Blake, J. J., Banks, C. S., Patience, B. A., \& Lund, E. M. (2014). School-based mental health professionals' bullying assessment practices: A call for evidence-based bullying assessment guidelines. Professional School Counseling, 18, 136-147. https://doi.org/10.5330/2156-759X-18.1.136

Chandler, J. W., Burnham, J. J., Riechel, M. E. K., Dahir, C. A., Stone, C. B., Oliver, D. F., ... Bledsoe, K. G. (2018). Assessing the counseling and non-counseling roles of school counselors. Journal of School Counseling, 16(7).

Creswell, J.W. (2013). Qualitative inquiry \& research design: Choosing among five approaches (3rd ed.). SAGE Publications, Inc.

Creswell, J. W., \& Creswell, J. D. (2017). Research design: Qualitative, quantitative, and mixed methods approaches. Sage publications.

Cronin, S., Ohrtman, M., Colton, E., Crouse, B., Depuydt, J., Merwin, C., \& Rinn, M. (2018). School counselor technology use and school-family-community partnerships. Journal of School Counseling, 16(6).

Dahir, C. A., \& Stone, C. B. (2012). The transformed school counselor. Brooks/Cole.

Dunlop Velez, E. (2016). How can high school counseling shape students' postsecondary attendance? Alexandria, VA: National Association for College Admission Counseling.

Dvorsky, M. R., Girio-Herrera, E., \& Owens, J. S. (2014). School-based screening for mental health in early childhood. In M. West (Ed.), Handbook of school mental health (pp. 297-310). Springer Publishing. https://doi.org/10.1007/978-1-4614-7624-5_22

Ecker-Lyster, M., \& Niileksela, C. (2016). Keeping students on track to graduate: a synthesis of school dropout trends, prevention, and intervention initiatives. Journal of At-Risk Issues, 19(2), 24-31.

Erford, B. T. (2011). Transforming the school counseling profession (3rd ed.). Pearson Education, Inc.

Freeman, J. Simonsen, B. McCoach, B., Sugai, G., Lombardi, A., \& Horner, R. (2015). An analysis of the relationship between implementation of school-wide positive behavior interventions and supports and high school dropout rates. High School Journal, 98(4), 290-314. https://doi.org/10.1353/hsj.2015.0009

Hani, M. (2000). Best practices for implementing remote learning during a pandemic. The Clearing House: A Journal of Educational Strategies, Issues and Ideas, 93(3), 135-141. 
Havlik, S., \& Bryan, J. (2015). Addressing the needs of students experiencing homelessness: School counselor preparation. The Professional Counselor, 5(2), 200-216. https://doi.org/10.15241/sh.5.2.200

Holman, L. F., Watts, R., Robles-Pina, R., \& Grubbs, L. (2018). Exploration of potential predictor variables leading to school counselor burnout. Journal of School Counseling, 16(9). https://doi.org/10.15241/lfh.9.2.126

Jobes, D. A., Crumlish, J. A., \& Evans, A. D. (2020). The COVID-19 pandemic and treating suicidal risk: The telepsychotherapy use of CAMS. Journal of Psychotherapy Integration, 30(2), 226-237. https://doi.org/10.1037/int0000208

Karaman, M. A., Esici H, Tomar I. H., \& Aliyev, R. (2021). Covid-19: Are school counseling services ready? Students' psychological symptoms, school counselors' views, and solutions. Frontiers in Psychology, 12, 647740-647740. https://doi.org/10.3389/fpsyg.2021.647740

MacMullin, K., Jerry, P., \& Cook, K. (2020). Psychotherapist experiences with tele psychotherapy: Pre COVID-19 lessons for a post COVID-19 world. Journal of Psychotherapy Integration, 30(2), 248-264. https://doi.org/10.1037/int0000213

McMahon, G., Mason, E., Daluga-Guenther, N., \& Ruiz, A. (2014). An ecological model of professional school counseling. Journal of Counseling and Development, 92, 459-471. https://doi.org/10.1002/j.1556-6676.2014.00172.x

Miles, M. B., Huberman, A. M., \& Saldana, J. (2014). Qualitative data analysis: A methods sourcebook. Sage.

Miller, P. (2011). A critical analysis of the research on student homelessness. Review of Educational Research, 81, 308-337. https://doi.org/10.3102/0034654311415120

National Board for Certified Counselors. (2012). Policy regarding the provision of distance professional services.

Olasile B. A., \& Emrah, S. (2020). Covid-19 pandemic and online learning: the challenges and opportunities, Interactive Learning Environment, 1-13. https://doi.org/10.1080/10494820.2020.1813180

Osborn, D. S., Peterson, G. W., \& Hale, R. R. (2015). Virtual School Counseling. Professional School Counseling, 18(1), 179-190. https://doi.org/10.5330/2156-759X-18.1.179

Pfefferbaum, B., \& North, C. S. (2020). Mental health and the Covid-19 pandemic. New England Journal of Medicine, 383, 510-512. https://doi.org/10.1056/NEJMp2008017

Pyne, J. R. (2011). Comprehensive school counseling programs, job satisfaction, and the ASCA national model. Professional School Counseling, 15, 88-97. https://doi.org/10.1177/2156759X1101500202

Radford, A. W., Ifill, N., \& Lew, T. (2016). A national look at the high school counseling office: What is it doing and what role can it play in facilitating students' path to college? National Association for College Admission Counseling.

Rosen, C. S., Glassman, L. H., \& Morland, L. A. (2020). Telepsychotherapy during a pandemic: A traumatic stress perspective. Journal of Psychotherapy Integration, 30(2), 174-187. https://doi.org/10.1037/int0000221

Sabella, R. A., \& Halverson, B. (2004). Building virtual communities in school counseling. In G. R. E. Waltz \& C. E. Kirkman (Eds.), Cyberbites: Highlighting compelling issues of technology in counseling. 1-5. University of North Carolina.

Schouten, R., Callahan, M. V., \& Bryant, S. (2004). Community response to disaster: The role of the workplace. Harvard Review of Psychiatry, 12(4), 229-237. https://doi.org/10.1080/10673220490509624

Sears, S. J., \& Granello, D. H. (2002). School counseling now and in the future: A reaction. Professional School Counseling, 5, 164-171.

Setia, M. S. (2016). Methodology series module 3: Cross-sectional studies. Indian Journal of Dermatology, 61(3), 261-264. https://doi.org/10.4103/0019-5154.182410

Springer, S., Paone, C. H., Colucci, J., \& Moss, L. J. (2020). Addressing suicidality: Examining preservice school counselors' perceptions of their training experiences. Journal of Child and Adolescent Counseling, 6(1), 18-36. https://doi.org/10.1080/23727810.2018.1556990

Steele, T., Jacokes, D., \& Stone, C. (2014). An examination of the role of online technology in school counseling. Professional School Counseling, 18(1), 125-135. https://doi.org/10.1177/2156759X0001800118

Strawser, S., Markos, P., Yamaguchi, B.J., \& Higgins, K. (2000). A new challenge for school counselors: Children 
who are homeless. Professional School Counseling, 3(3), 162-171.

Talmus, L. (2019). Tackling social isolation in middle school. Childhood Education, 95(6), 42-49. https://doi.org/10.1080/00094056.2019.1689058

Tompsett, C. J., \& Toro, P. A. (2010). Predicting overt and covert antisocial behaviors: parents, peers, and homelessness. Journal of Community Psychology, 38(4), 469-485. https://doi.org/10.1002/jcop.20375

Torales, J., O’Higgins, M., Castaldelli-Maia, J. M., \& Ventriglio, A. (2020). The outbreak of COVID-19 coronavirus and its impact on global mental health. International Journal of Social Psychiatry, 66(4), 317-320. https://doi.org/10.1177/0020764020915212

Twenge, J., \& Joiner, T. E. (2020, May 7). Mental distress among U.S. adults during the COVID-19 pandemic. https://doi.org/10.31234/osf.io/wc8ud

van Heugten, K. (2012). Workplace stress in the aftermath of a natural disaster. In Hall, N. (ed), Social work around the world V: Building the global agenda for social work and social development (pp. 41-52). International Federation of Social Workers.

Viner, R. M., Russell, S. J., Croker, H., Packer, J., Ward, J., Stansfield, C., ... Booy, R. (2020). School closure and management practices during coronavirus outbreaks including COVID-19: a rapid systematic review. The Lancet Child \& Adolescent Health, 4, 397-404. https://doi.org/10.1016/S2352-4642(20)30095-X

Wilczenski, F. L., \& Coomey, S. M. (2006). Cyber-communication: Finding its place in school counseling practice, education, and professional development. Professional School Counseling, 9, 327-331. https://doi.org/10.5330/prsc.9.4.78t6014366615205

Wilder, C. (2018). Promoting the role of the school counselor. Journal of Professional Counseling: Practice, Theory \& Research, 45(2), 60-68. https://doi.org/10.1080/15566382.2019.1646085

Wong, C. A., Ming, D., Maslow, G., \& Gifford, E. J. (2020). Mitigating the impacts of the COVID-19 pandemic response on at-risk children. Pediatrics, 145(4), e20200973. https://doi.org/10.1542/peds.2020-0973

Wood, C., Wilkerson, K., Perusse, R., \& Hughes, A. (2013). Comprehensive school counseling programs and student achievement outcomes: A comparative analysis of ramp versus non-ramp schools. Professional School Counseling, 16, 172-184. https://doi.org/10.5330/PSC.n.2013-16.172

Woods. C. S., \& Domina, T. (2014). The school counselor caseload and high school-to-college pipeline. Teachers College Record, 116(10), 1-30. https://doi.org/10.1177/016146811411601006

Yablon, Y. B. (2019). School safety and school connectedness as resilience factors for students facing terror. School Psychology, 34(2), 129-137. https://doi.org/10.1037/spq0000259

Zalaquett, C. P., \& Chatters, S. J. (2012). Middle school principals' perceptions of middle school counselors' roles and functions. American Secondary Education, 40, 89-103.

\section{Appendix}

Qualitative Themes \& Codes

\begin{tabular}{ll}
\hline \multicolumn{1}{c}{ Theme } & \multicolumn{1}{c}{ Codes } \\
\hline Technology/ Connectivity & Access to the internet, computer access, technical support \\
Student Response & $\begin{array}{l}\text { Engaged students, lack of connecting with students, distracted by stimuli in } \\
\text { the home when on zoom. }\end{array}$ \\
Confidentiality & $\begin{array}{l}\text { Students are reluctant to share over the phone, they have parents or siblings at } \\
\text { home that could overhear, parents are reluctant to allow private conversations. }\end{array}$ \\
Personal Contact, Trust, Rapport & $\begin{array}{l}\text { Impossible to hug or hold a hand or reach out and touch for comfort. } \\
\text { Lack of parental support (Emergent code) }\end{array}$ \\
Parents not signing students up for virtual options. \\
Working at home & $\begin{array}{l}\text { Multiple interruptions from family, establishing a consistent daily routine, } \\
\text { constraints of participating and feeling connected in ZOOM meetings, }\end{array}$ \\
completing paperwork and keeping records. \\
Unable to connect with students (lack of & $\begin{array}{l}\text { Changed phone numbers or disconnected phone services, being able to get } \\
\text { contact information) }\end{array}$ \\
\hline
\end{tabular}


Lack of experience working online

How to connect with students.

Practicing online counseling session

Learning about useful technology tools

Potential variations in responsibility

Advocacy for the importance of counseling.

Lack of experience with online counseling

Technology/ Connectivity

Balancing family and work

Lack of experience counseling online

Communication challenges with students and parents (Emerging)

Communication with co-workers

Time Management

A shift in role responsibilities

Appropriate workspace

Food and hygiene and school supplies and housing (resources) to families

Coordinating student-teacher contact

Monitoring Student Learning

Planning for re-entry

No Additional Roles

Coordinating social media

Online counseling

Social-Emotional Learning Resources

Coordinating LMS and student assignments

Working more directly with the social worker
Body language issue

Lack of resources among each household when using technology, student access to technology and internet, locating students during pandemic, limited communication with teachers/ administration.

Getting the students to participate in google meets and counseling lessons on DoJo Classroom and Google Classroom.

Learning how to integrate additional technology to deliver effective lessons and group meets.

Appropriate reporting procedures

Inability to identify students with needs, getting the word out to let students know counselor is still available.

Training and Application

Students do not have phone or internet access, most parents do not answer the phone, respond more often to text messages but with concise responses, very few students check their email.

Everyone is overwhelmed, family obligations

Student engagement, not knowing how to motivate students to reach out online during the pandemic

Internet freezing or garbled during group meetings, sharing screen without being kicked out of meetings, students are not always available or online during group time.

Internet issue, not being prepared, lack of adequate information

More time to do school work and family work from home.

Home delivery of food to parents in need

Separating work from home has been hard without an office.

Overwhelmed by students' needs, access to parents

Heavy workload, lack of collaborative effort.

Unable to reach the number of students like while working in the school building.

Safety precautions

Working at school three days a week.

Creating awareness to parents

Getting students to connect and participate with counselor assignments as well as their academic assignments

Lack of information

Building the master schedule

Lack of adequate resources

\section{Copyrights}

Copyright for this article is retained by the author(s), with first publication rights granted to the journal.

This is an open-access article distributed under the terms and conditions of the Creative Commons Attribution license (http://creativecommons.org/licenses/by/4.0/). 